\title{
Collaborative Governance Model Integrated Waste Management in Bandung City
}

\author{
Jati Puspita Rini*, Ely Sufianti, Sait Abdullah \\ Public Development Administration Department \\ Politeknik STIA LAN \\ Bandung, Indonesia \\ *ariniahdaka@gmail.com
}

\begin{abstract}
The purpose of this study is: 1) To figure out the collaboration model between the government and stakeholders in the existing waste management in the city of Bandung. 2) To analyze the problems in the collaboration model between the government and stakeholders in waste management in the city of Bandung. 3) To formulate and recommend the Collaborative Governance Model of Integrated Waste Management which is ideally applied in the City of Bandung. The research method used is descriptive research through a qualitative approach. Collecting data obtained in this study through several field studies. In this study using Nonprobability sampling techniques, specifically using Purposive Sample. The data analysis technique used in this study is qualitative data analysis following the concept of Miles and Huberman. In this study, researchers used the theory of Ansell and Gash in the study of integrated waste management collaboration in the city of Bandung. Conclusions after reviewing descriptive qualitative exposures and carrying out direct observations in the field, it was found that collaboration and division of stakeholder roles were not yet running. In addition, the problems faced in the waste management process are still quite complex, so the researcher recommends an ideal Collaborative Governance Model of Integrated Waste Management that is applied in Bandung in accordance with available resources. Researchers recommend a Collaborative Governance Model of Integrated Waste Management in the city of Bandung into three stages of management: 1) Collaborative management from sources; 2) Regional Scale Collaborative waste management, and 3) City Scale waste management.
\end{abstract}

Keywords-waste management, collaborative governance, Penta helix

\section{INTRODUCTION}

The problem of urban waste in Indonesia is a problem that has not been completely resolved. The amount of waste in urban areas is increasing along with rapid urbanization due to the impact of socio-economic development. Uncontrolled population growth and urban expansion (urban sprawl) are increasingly adding to waste generation in cities. Total waste generated by the community is estimated that only $60 \%-70 \%$ is transported to the landfill by the party who handles it (Source: PD Cleaning Bandung City: 2018). Most of the waste that is not handled by the government is usually burned or thrown into the river and only a small part is processed or handled by scavengers. The local government, which is trusted to handle waste management, has not been able to resolve this problem optimally.

Based on the above problems, the author identifies several problems that arise in the waste management of Bandung City. The phenomenon commonly seen in the city of Bandung still shows that the waste problem in the city of Bandung is still very heavy in terms of waste management, which until now as a whole still uses the collect - transport - throw method, but it still leaves many problems. Strategic efforts made in integrating and synergizing waste management with stakeholders have not shown a significant reduction in problems.

Based on the description in the background to the problem above, the researcher formulates the research problem as follows:

- How is the existing collaborative governance model for waste management in Bandung City today?

- How is the implementation of integrated / integrated waste management in Bandung City?

- What are the inhibiting factors in collaborative governance between local government and stakeholders, in this case the community, business world, NGOs, and other institutions in waste management in Bandung City?

- How is the ideal collaborative governance model implemented in Bandung City?

\section{LITERATURE REVIEW}

The current development paradigm according to Sufianti [1] is no longer dependent on the role of the government alone (government) but develops into development that involves stakeholders (governance). As a concept, governance has various meanings expressed by several experts. According to Dwiyanto [2], the concept of governance is the involvement of actors outside the government who respond to public problems. 
The concept of collaborative governance is currently an important and interesting study in the context of development policy. The complexity of developments, conditions, and challenges experienced by the government demands the implementation of a concept that can accommodate the integration of stakeholders who jointly collaborate in governance. Anshell and Grash [3] state that the concept of collaborative governance is a response to the failures experienced by the government, such as failure in terms of implementation and the emergence of politicization of a policy due to the domination of a single actor in its formulation.

The concept of collaborative governance according to Ansell and Gash [3] emphasizes collaboration carried out by 3 sectors at once, namely the public agency through the government, the private sector which refers to the private sector, and community participation both individually and in groups. Besides that, Ansel and Gash and the government act as the initiator of the collaboration. Collaborative governance does not emphasize the government as the initiator. Collaborative governance is defined as the process and structure of making and implementing public policies that involve parties within the scope and level or level of government agencies and / or the private sector and civil society to manage the interests or needs of the community so that they can be achieved.

Collaboration in the Penta helix concept is a collaborative activity between the fields of academic, business, community, government, and media, otherwise known as ABCGM. Collaboration in the Penta helix concept itself is also one of the keys to building synergies to improve the quality and capacity of stakeholders in integrated waste management. This can be a new effort for the Bandung City government to involve all stakeholders in solving the waste problem in Bandung City.

\section{RESEARCH METHODS}

The research method used is descriptive research through a qualitative approach. The purpose of this descriptive research is to make descriptions, descriptions, or paintings systematically, factually, and accurately regarding the facts, characteristics and relationships between the phenomena being investigated [4]. Information or data in qualitative research is descriptive. Data can be in the form of symptoms, events and events which are then analyzed in the form of categories.

Collecting data obtained in this study through several field studies. Field studies are techniques or research methods in which the researcher goes directly to the field to obtain the required data. In selecting the sample, this study uses a sampling technique, nonprobability sampling, or which means a sampling technique that does not provide equal opportunities / opportunities for each element or member of the population to be selected as samples [5].

The sampling technique in this study uses a purposive sample. Data taken by field observations and interviews. Meanwhile, for data analysis techniques, there are three main components that must be considered in presenting qualitative data, namely data reduction, data presentation and drawing conclusions or verification [4]. After that, the credibility test was carried out in this study by increasing persistence, data triangulation, and member checks.

\section{RESULTS AND DISCUSSION}

Bandung City is administratively located in West Java Province. Based on data obtained by researchers from the Bandung City Waste Master Plan, published by Bappelitbang in 2018, Bandung City has an area of $167.31 \mathrm{~km} 2$ or approximately $16,731 \mathrm{Ha}$. According to the Bandung City Regulation Number 06 of 2007 concerning the Expansion and Establishment of Sub-District and Sub-District Work Areas in the Bandung City Government, it consists of 30 Districts and 151 Sub-districts. From each sub-district there are 9,677 Rukun Tangga (RT) and 1,560 for Rukun Warga.

Municipal solid waste management is a basic infrastructure requirement that must be met within the framework of sustainable urban development management.

From the research results, it can be seen that as a regional company entrusted with the duties and functions of waste management in the city of Bandung, PD Cleaning only focuses on how the process of distributing waste from source to final processing site or TPA. PD Cleaning works on the operational technicalities of transporting waste from the source to the landfill, DLHK encourages waste to be reduced first directly from the source through various recommended methods, including composter, biodigester, biopore holes, or recycling waste into goods of economic value.

From the research results of various stakeholder collaborations that have been carried out in Bandung, which were analyzed based on 3 indicators, namely participation, partnerships, and networks of pentahelix stakeholders. One of the collaborative models that has been implemented is waste management through the KangPisMan Program, which is a waste management program that implements it regularly and handles it from the source. Only implementation in the field still has to be controlled, both from regulations / regulations, institutions, financing, operational techniques, and community participation.

From the results of the research, only 8 urban villages and 64 RWs have become pilot projects of 1560 RWs in Bandung City. Waste management through KangPisMan which is very effective in reducing waste residue, but the problem has not been effectively implemented thoroughly in the city of Bandung.

\section{A. Analysis of Community Participation Aspects}

The distribution of community participation in Bandung City regarding existing waste management tends to be low. The number of people who play a role as waste processors is still very small. This can be seen from the high amount of waste generation in 2019 and reaching approximately 1500.10 tons / day. The process of community participation in waste 
management, which has been counted only in the 8 subdistricts of the pilot area, consists of 64 RWs. They began to sort and utilize waste and tried to reduce the amount of waste sent to the TPS. Community participation, which can then be seen from community involvement in the Waste Bank. Meanwhile, there are only 84 waste banks that have joined as a unit of the Bandung City risk waste bank with a total customer base of 3,207 people. The current form of participation is in the form of charity rubbish, saving garbage, or using waste to become items of economic value.

Participation movements from the community, community organizations, business / entrepreneur sector, media, and academics have started to run the zero-waste area program which is now echoed as the Kang PisMan program. However, it is true that there has been no effective collaboration between institutions, so the success rate of the movement tends to be overlooked. The results of the research show that in Bandung there are approximately 144 agencies, schools, and waste bank units, as well as foundations that participate in waste management in the city of Bandung. Of the many participants who manage waste in Bandung City, however, they have not shown a decrease in the volume of waste transported to the TPA.

The forms of participation that have been carried out by the community in waste management are implementing various preventive / preventive activities or activities to reduce waste from sources including: Trying to spend food at the household level, reducing the habit of using food product packaging, reducing the use of plastic when shopping, carry out the garbage collection movement, carry out activities to reduce waste from the source, carry out the reduction of waste from the source, through the Waste Bank and TPS 3R.

\section{B. Partnership Aspect Analysis}

Regarding the discussion of partnerships, the researcher obtained from the results of field observations, that the partnership previously carried out by the Bandung City Sanitation PD was not yet fully effective. It can be said that because each agency and stakeholder that carried out the partnership had not carried out its function properly.

The data obtained shows that in 2017 the number of RWs implementing the MoU was $1478 \mathrm{RW}$, in 2018 there were $1516 \mathrm{RWs}$, and in 2019 as many as $1535 \mathrm{RWs}$ have carried out a partnership with PD Cleaning Bandung City. This form of partnership is still in the form of an agreement to collect waste from the TPS to the TPA, but the institutional function of the $\mathrm{RW}$ as a waste management unit from sources is not optimal, we cannot blame the RW heads either, because in fact there are no assisting officers from PD Cleaning or DLHK who are assigned to implement socialization and education to members of the community. Just starting in mid-2020, the implementation of massive socialization and education began to be carried out simultaneously in Bandung City.

In addition, the Waste Bank program is a form of partnership established by both DLHK and PD Cleaning as the leading waste management sector from regulatory and operational aspects. The researcher found that the number of waste banks in Bandung was 467 waste banks, both assisted and independent waste banks. The city of Bandung has 2 (two) main waste banks, namely the Green Waste bank and the Bandung Resik waste bank which is under the auspices of the Bandung City Sanitation PD. This main waste bank houses a small garbage bank in the vicinity. Green waste bank Lestari houses 119 small waste banks and Bandung Resik garbage bank houses 93 garbage banks.

\section{Network Aspect Analysis}

The importance of networking in waste management to create a community that understands waste management programs, in this case in Bandung City is the Kang Pisman program, namely reducing, separating and utilizing it. The development of waste management groups gives new hope for the success of waste management in Bandung City, which not only focuses on the transportation process, but more on the process of reducing waste from the source.

Many things have been done by the city government of Bandung, in this case DLHK and PD Cleanliness in forming a waste management network. Among them through media such as facebook, Twitter, Instagram, and websites. In total, there are more than 8000 involved in becoming followers of KangPisMan social media accounts on the three platforms, and more than 280 content created and shared by the KangPisMan account. Based on the results of field observations, socialization and assistance in developing networks is still not optimal. The implementation of activities is still running on a budget basis.

There are still many efforts and strategies that need to be developed in order to build a collaborative waste management network in Bandung City. Among them, through program optimization through online media, offline socialization, conducting Focus Group Discussions (FGD) on waste management, forming, and developing waste management communities, forming waste volunteers, increasing the role and function of sub-district and sub-district institutional functions in waste management, and collaborating roles - external roles such as scavengers / collectors in Bandung.

Taking into account that the collaboration is still not optimal, with indicators of the still high volume of waste transported from the TPS to the TPA, the authors attempt to create a model of Collaborative Governance Management of $\mathrm{Sa}$ as follows: 
1) Collaborative governance model integrated waste management in Bandung

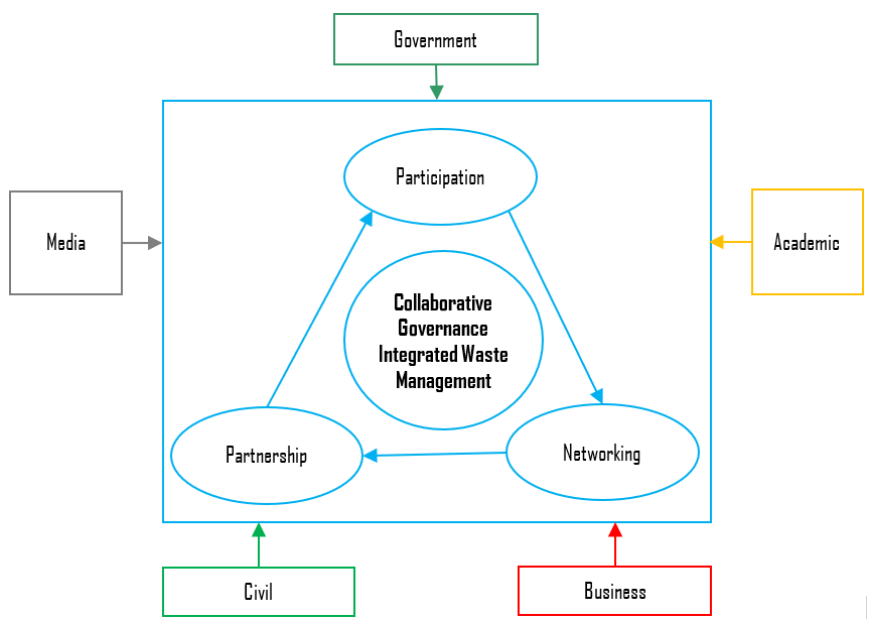

Fig. 1. Waste management stakeholders with the Penta helix model.

Ideally, various types of problems can be resolved through collaborative governance-based integrated waste management. Collaborative Governance in integrated waste management requires a conditioning stage that uses the Penta helix model, meaning that the elements involved are cross-sector, starting from the government, society / community, the business world. Entrepreneurs, academics and the media. Questions about when the collaboration process will take place.

Based on the model above (Figure 1), of course the researcher tries to make a strategy and contribution of stakeholders in collaboration, which is divided into three stages of the collaboration model, namely by early handling at the source scale and optimization of waste prevention (household / settlement scale), Implementing a new paradigm of scale waste management. Gradual waste reduction areas through proper and correct waste processing and control of the amount of waste transported to the TPA, by building or developing regional / sub-district and sub-district waste processing sites, implementing a new paradigm of waste management in Bandung City by gradually reducing the transportation cost to the Sarimukti TPA efforts towards the City of Bandung as a Waste Free Area.

\section{2) Regional scale waste management}

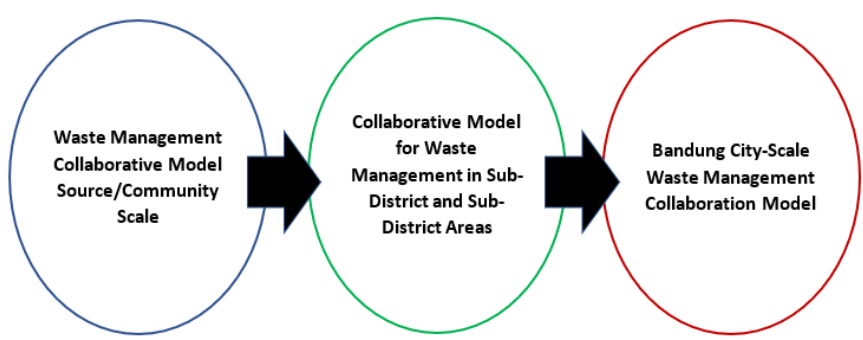

Fig. 2. Advice on waste management through regional-scale stakeholder collaboration.

\section{CONCLUSION AND SUGGESTION}

\section{A. Conclusion}

The problem of waste management can never be resolved if it only relies on government solutions without the involvement of the community and other stakeholders as a source of waste income itself. The collaborative model developed based on the Ansell and Gash theory processed by researchers includes 3 indicators, namely participation, partnership, and networking among the stakeholders of the Penta helix, known as ABCGM, namely Academics, Business, Community, Government, Media.

From the results of the discussion presented in a qualitative descriptive presentation, the researcher found that the existing waste management had gone according to the conventional pattern, namely collect - transport - throw away. However, starting from the leadership of the Mayor of Bandung, Oded M. Danial, who launched the KangPisMan program. Researchers recommend a collaborative governance model of management in Bandung City into three stages of management, namely:

- Collaborative management from sources.

- Collaboration of regional scale waste management, and

- City scale waste management.

In this way, various stakeholders, and stakeholders from the household level to the city level will have a role in contributing to the handling of solid waste in Bandung City.

\section{B. Suggestion}

Researchers suggest several aspects to improve the quality so as to encourage the optimization of waste management effectively and efficiently, namely:

- There is a need for mapping of key stakeholders.

- Increase community empowerment and independence in waste management.

- Develop studies on the use of environmentally friendly and sustainable technology involving potential resources in waste management.

- Forming a waste management collaboration team in Bandung City starting from the household and community scale, area scale, and city scale, to strengthen the institutionalization of waste management.

- Determine the role of each stakeholder and create a measurement instrument for the success of collaborative waste management. 


\section{REFERENCES}

[1] E. Sufianti, Planning Collaboration in Waste Management for Sustainable Environmental Development, Bnadung: STIA LAN Bandung, 2011, pp.322.

[2] A. Dwiyanto, Realizing Good Governance through Public Services. Yogyakarta: Gadjah Mada University Press. 2008. pp.22.
[3] C. Ansell and A. Gash, Collaborative Govetnance in Theory and Practice. Journal of Public Administration Administration Research and Theory, 2007, pp.545.

[4] J.M. Lexy, Qualitative Research Methods, Bandung: Youth Rosda Karya, 2007, pp.49.

[5] Sugiyono, Educational Research Methods with qualitative approaches, quantitative R\&D, Bandung: Alfabeta, 2011, pp.122. 